Çukurova Üniversitesi Mühendislik Mimarlık Fakültesi Dergisi, 31(1), 203-212 ss., Haziran 2016

Çukurova University Journal of the Faculty of Engineering and Architecture, 31(1), pp. 203-212, June 2016

\title{
Çukurova Üniversitesi Balcalı Kampüsü Kuzey Çarşı Projesi
}

\author{
Onur ERMAN*1 \\ ${ }^{1}$ Çukurova Üniversitesi, Mühendislik-Mimarlık Fakültesi, Mimarlık Bölümü, Adana \\ Geliş tarihi: 21.01.2016 Kabul tarihi: 07.03.2016
}

\section{Özet}

Çalışma, Yrd. Doç. Dr. Onur ERMAN tarafindan Aralık 2012'de tasarımına başlanan ve Mart 2013'de tamamlanarak Çukurova Üniversitesi Rektörlüğüne teslim edilen Çukurova Üniversitesi Balcalı Kampüsü Kuzey Çarşı Projesi tanıtılmaktadır. Çalışmada projeye ilişkin tasarım süreci ve tasarımda öne çıkan unsurlar ile geliştirilen projede önerilen mekân kullanımıyla alansal büyüklükler sunulmaya çalışılmıştır. Projenin uygulanmasına Mayıs 2015'de başlanmış, yapımı halen devam etmektedir.

Anahtar Kelimeler: Çukurova Üniversitesi, Kampüs çarşı projesi, Mimari tasarım, Öğrenci sosyal merkezi, Adana.

\section{Çukurova University Balcalı Campus North Shopping Area Project}

\begin{abstract}
The purpose of the paper is to introduce of the Çukurova University Balcalı Campus North Shopping Area Project, which was started to design by Assist. Prof. Dr. Onur ERMAN on December 2012 and submitted to the Çukurova University Rectorate on March 2013. The design process and featured issues of the project and proposed spatial uses and areal sizes were tried to present in the manuscript. The construction process of the project started on May 2015 and still continues.
\end{abstract}

Keywords: Çukurova University, Campus shopping area project, Architectural design, Student social center, Adana.

\footnotetext{
*Yazışmaların yapılacağı yazar: Onur ERMAN, Çukurova Üniversitesi, Mühendislik Mimarllk Fakültesi, MimarlıkBölümü, Adana. oerman@cu.edu.tr
} 


\section{GíRiș}

Üniversite kampüsleri ana faaliyet olan eğitimin gerektirdiği hizmet alanları ile diğer destek kullanımlarına imkân tanıyan fiziki yapılanmalardır. Üniversitelerde kampüs oluşumunun temel amacı fakülte ve birimlerde sürdürülen eğitsel faaliyetlerin koordineli bir biçimde sürdürülmesini sağlamaktır. Kampüs yerleşkeleri neredeyse küçük bir şehir gibi biçimlenerek yönetim, eğitim, barınma, sağlık, alışveriş ve kültürel amaçlı hizmet veren yapıları bünyesinde barındırır. $\mathrm{Bu}$ bakımdan kampüs yerleşkeleri salt eğitim ve yönetim yapılarından oluşmaz. Eğitim faaliyetlerini destekler biçimde kullanıcıların günlük yaşam içinde ihtiyaç duydukları diğer hizmet alanlarını ve özellikle kullanıcıların sosyal ve kültürel yaşamını destekleyen yapıları da içerir. Böylelikle kampüs;

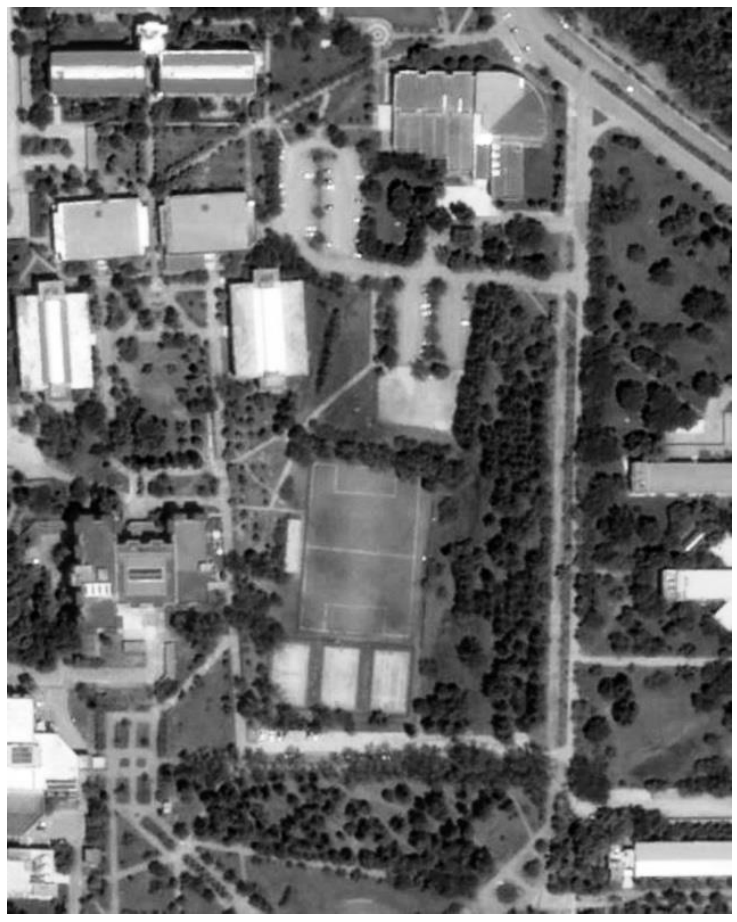

A) Mayls 2014 tarihli hava fotosu, Google Earth eğitim zamanı içinde kullanılan bir alan olmaktan sıyrılarak yaşayan, canlı bir fiziki bütüne dönüşür. Çukurova Üniversitesi uluslararası ölçekte etkiye sahip Türkiye'nin köklü üniversitelerinden birisidir. 17 Fakülte, 4 Yüksekokul, 12 Meslek Yüksekokulu, 1 Devlet Konservatuvarı, 3 Enstitü ve 32 Araştırma ve Uygulama Merkezini bünyesinde barındıran Çukurova Üniversitesinde 2015 yılı Eylül ayı verilerine göre 2186 Akademik Personel, 44.697'si lisans ve ön lisans ve 5.014'si lisansüstü olmak üzere 49.711 öğrencinin eğitim ve öğretiminde görev almaktadır. Kent merkezinin uzağında konumlandırılan Çukurova Üniversitesi Balcalı Kampüsünde, kullanıcıların büyük kısmını oluşturan öğrencilerin eğitim faaliyetleri dışında kalan zamanının değerlendirilmesi ve günlük ihtiyaçlarının karşılanması ancak kampüs içi olanaklarla sağlanabilmektedir.

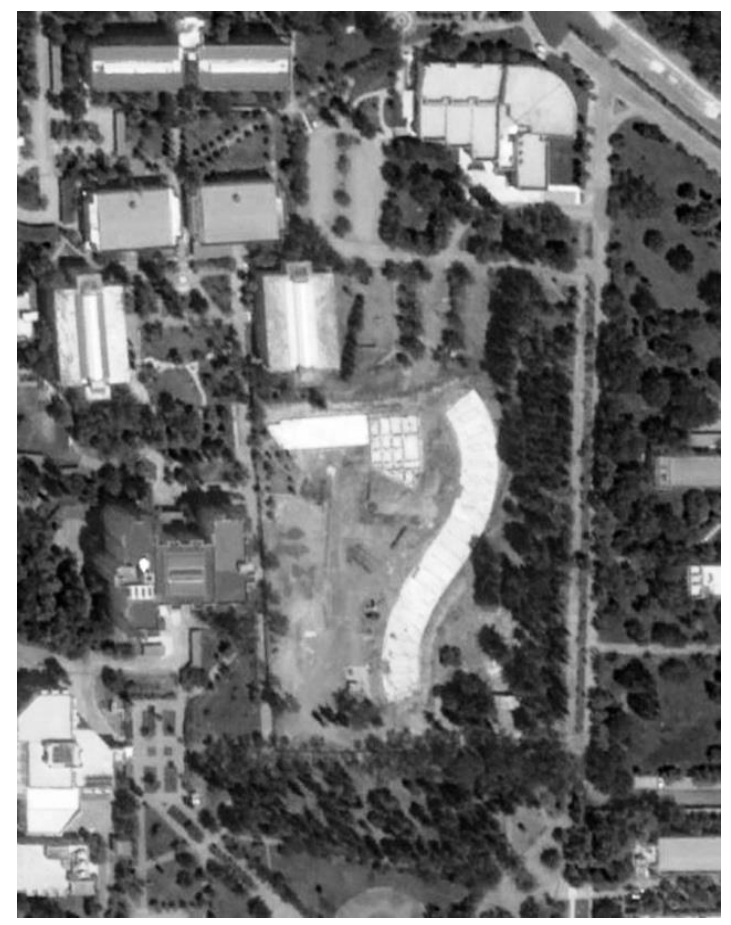

B) A ğustos 2015 tarihli hava fotosu, Google Earth

Şekil 1. Proje alanının Mayıs 2014 ve Ağustos 2015 tarihli hava fotoğrafları 
Gün içinde yaklaşık 50000 kişinin bulunduğu kampüste öğrenci, akademik ve idari personelin yeme içme, alışveriş gibi ihtiyaçlarını karşılamanın yanında kampüs kullanıcılarının sosyal ve kültürel ihtiyaçlarını karşılayacak ve kampüs yaşantısını zenginleştirecek bir yapılaşmaya ihtiyaç duyulmuştur. $\mathrm{Bu}$ doğrultuda Çukurova Üniversitesi Rektörlüğü Döner Sermaye İşleri aracılığıyla Çukurova Üniversitesi Mühendislik Mimarlık Fakültesi Öğretim Üyesi Yrd. Doç. Dr. Onur ERMAN tarafindan 2012 yılı Aralık ayında Kuzey Çarşı Kompleksinin projelendirme çalışmasına başlanmıştır. Üniversite Rektörlügü ile yapılan görüşmeler sonucunda Merkezi Kütüphane binasının doğusunda, R2 Binası ile Mithat Özsan Amfi grubunun güneyinde kalan ve futbol sahası olarak kullanılan alanda çarşı kompleksinin projelendirilmesine karar verilmiştir (Şekil 1).

\section{TASARIM SÜRECI}

Çarşı kompleksinin tasarım programı alışveriş, yeme içme birimleri, mescit, sinema salonu, sergi salonu, genel wc'ler, açık ve yarı açık mekan düzenlemesini kapsamaktadır. Tasarım programında istenilenlerin gerçekleşmesi ve tasarım kurgusunun oluşturulması amaciyla yapılaşma önerilen alanda yaya ulaşımı, araç yaklaşımı ve servis bağlantıları, mevcut yeşil doku, mevcut yapılaşma, topografya ve yön analizleri yapılmıştır. Tasarımın genelinde herkes için tasarım kriterleri dikkate alınarak kampüs içi yaya hareketine uyan ve yaya ulaşımını destekleyen bir öneri geliştirilmeye çalışılmıştır. Bu bakımdan öncelikle mevcut yaya davranışları gözlemlenmiş, alana ulaşımdaki ana yaya arterleri tespit edilmiştir (Şekil 2). Diğer taraftan arazinin topografik yapısı incelendiğinde mevcut kullanım nedeni ile futbol sahasının yerleştiği alanın düzleştirildiği, Mithat Özsan Amfisi ve R2 Binasının bulunduğu kısım (151 kotu) ile futbol sahasının bulunduğu alan (147 kotu) arasında 4 metrelik bir kot farkı bulunduğu tespit edilmiştir. 4 metrelik kot farkı kimi yerde doğal eğimle geçilirken, kimi yerde futbol sahası için yapılan düzenleme sonucu, kesin bir sınır oluşturan yükselti şeklindedir.

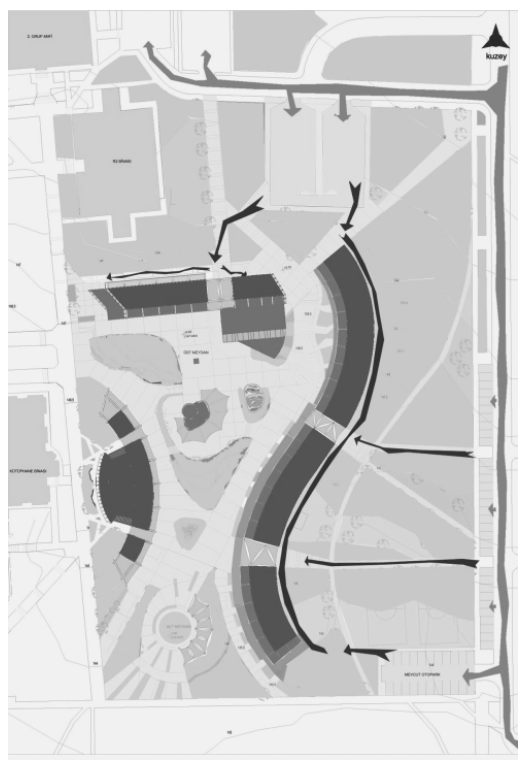

(B)

Şekil 2. Alanda mevcut duruma ilişkin saptamalar sonucunda önerilen yaya ulaşımı (A) ve araç-servis (B) yaklaşımı 
Arazi yapısındaki kot farklılıkları, tasarım kararlarına yansıtılarak, kotun 4 metre düştüğü yerde $\mathrm{Z}+1$ katlı bir yapının konumlanmasinı (Şekil 3, A işaretli yap1) ve 0.00 kotundan +4.00 kotuna ulaşmada kademeli olarak yükselen yapının (Şekil 3, D işaretli yapı) yerleştirilmesini sağlamıştır. Böylece Mithat Özsan Amfisi yönünden yaklaşımda kuzey cephesinde tek katlı olan yapı grubu, alanın güney yönünde $\mathrm{Z}+1$ katlı olarak biçimlenmiştir (Şekil 3, A işaretli yapı). Bu yapıya 151 kotundan giriş verilmiş, yapı içindeki düşey sirkülasyon elemanları ile 147 kotuna ulaşılmıştır. Kot farkının tasarıma sağladığı en önemli katkı ise $Z+1$ katlı sergi ve sinema yapı grubu ile kotla birlikte yükselen alışveriş birimi arasına konumlandırılmış basamaklardır. Mithat Özsan Amfisi yönünden yaklaşan kullanıcılar bu geniş basamaklar ve rampalardan inerek alana ulaşırken, alana hâkim bir manzarayla karşılanır.
Bu basamakların aynı zamanda açık amfi şeklinde düzenlenmesiyle çok amaçlı kullanılabilecek sosyal bir mekân oluşturulmaya çalışılmıştır. Yapıların güney-kuzey aksında konumlandırılması ile açık alanların iklimsel konfor koşulları sağlanmaya çalışılmış, açık alanların özellikle yazın ihtiyaç duyulan serinletici rüzgârı almasına ve kış mevsiminde ise güneşlenmesine önem verilmiştir. Yap1 formunun ve yerleşiminin belirlenmesinde mevcut yeşil doku dikkate alınmış, özellikle alanın doğusunda yer alan sık ağaçlıklı alana müdahale etmekten kaçınılmıştır. Yeşil dokunun sınırladığı alanda yap1 yüksekliklerinin insan ölçeğine uygun olmasına ve ağaç yüksekliklerinin aşılmamasına özen gösterilmiş, böylece yeşil doku ile uyumlu bir yapı bütünü oluşturulmak istenmiştir. $\mathrm{Bu}$ kararlar doğrultusunda vaziyet planı şekillendirilmiştir (Şekil 3).

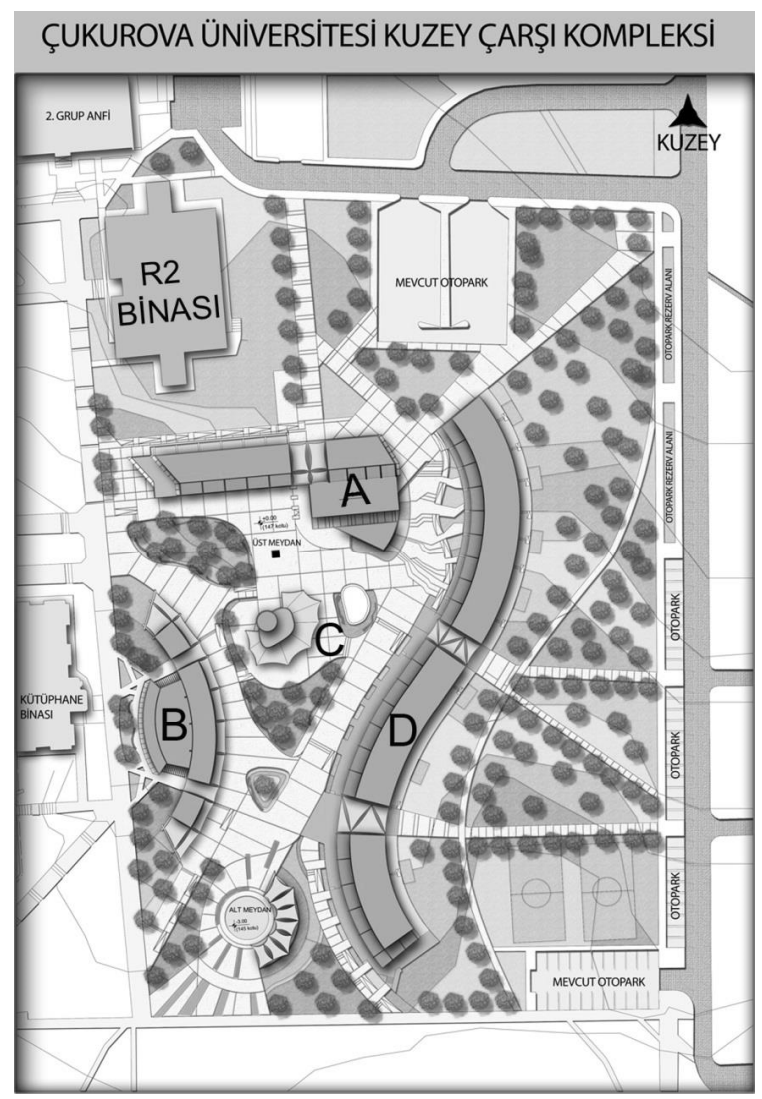

Alanda Önerilen Yapılar

A) Sinema, Sergi/Dükkân Grubu Yapısı

B) Mescit/Dükkân Grubu Yapist

C) Pastane Yaptsı

D) Kafe/Dükkân Grubu Yapıst

Şekil 3. Çukurova Üniversitesi Kuzey Çarşı Kompleksi vaziyet planı 


\section{ALANDA ÖNERILEN YAPILAR ve ALAN KULLANIMI}

\subsection{Kapalı Alan Kullanımı}

Yaklaşık $25000 \mathrm{~m}^{2}$ büyüklüğündeki arsa alanı içinde toplam $3175 \mathrm{~m}^{2}$ kapalı alan ve $1555 \mathrm{~m}^{2}$ yarı açık alan kullanımı önerilmektedir. Geriye kalan alan büyüklüğü rekreasyon, sirkülasyon ve yeşil alan kullanımı için düzenlenmiştir. Alanda dört adet yap1 grubu bulunmaktadır. Alanda projelendirilen yapıların plan şemaları ve alan kullanımları Çizelge 1, Çizelge 4'de verildiği gibidir.

Çizelge 1. Sinema, Sergi/Dükkân Grubu Yapısı mahal listesi ve alan kullanımı

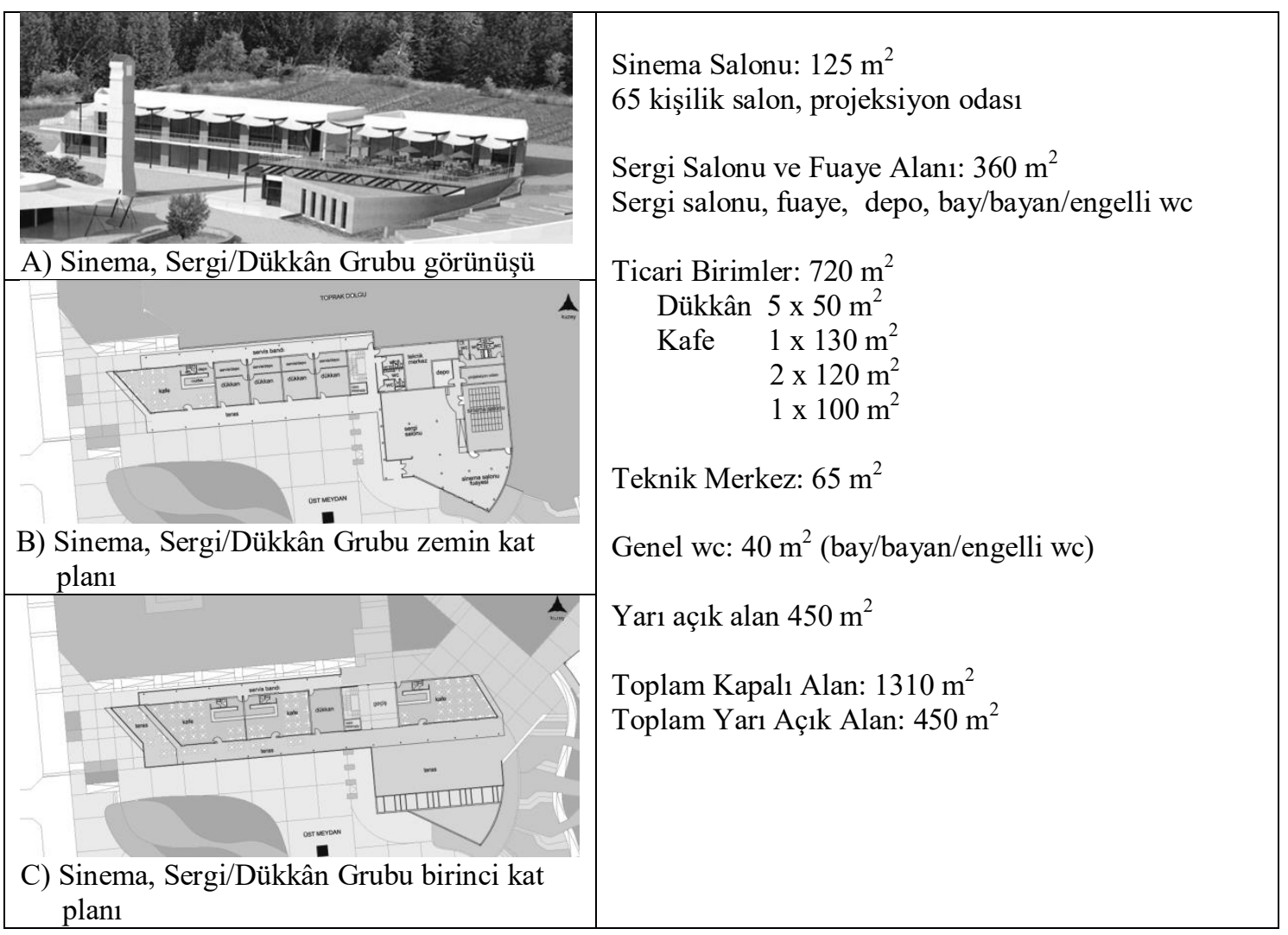

Alanın Kuzey yönünde yer alan ve $Z+1$ katlı olan Sinema, Sergi, Dükkan Grubu yapısında alt ve üst katlarda ticari birimler düzenlenmiş, yapının zemin katında sergi salonu, fuayesi ve 65 kişilik bir sinema salonu tasarlanmıştır. Yapıda farklı büyüklüklerde kafe birimleri oluşturulmuş, alt ve üst katta yer alan bu birimlerde yarı açık alan kullanımı sağlanmaya çalışılmıştır (Çizelge 1). Genel kullanıma ait wc'lerin bir bölümü ve teknik servis birimi de bu yapı içinde yer almaktadır.
Mescit Dükkan Grubu yapısının içinde dükkanlar alana yönlendirilmiş, bay ve bayan mescidininse alandan bağımsız olarak kullanımına imkan tanınmıştır. Ana yaya arteri üzerinde bulunan bu yapıda ayrıca ATM üniteleri yer almaktadır (Çizelge 2). Pastane birimi ise alana hakim bir noktada konumlandirılarak, kapalı alan kullanımının yanında güney yönüne hakim yarı açık alan kullanımı sağlanmıştır (Çizelge 3). 
Çizelge 2. Mescit/Dükkan Grubu Yapısı mahal listesi ve alan kullanımı
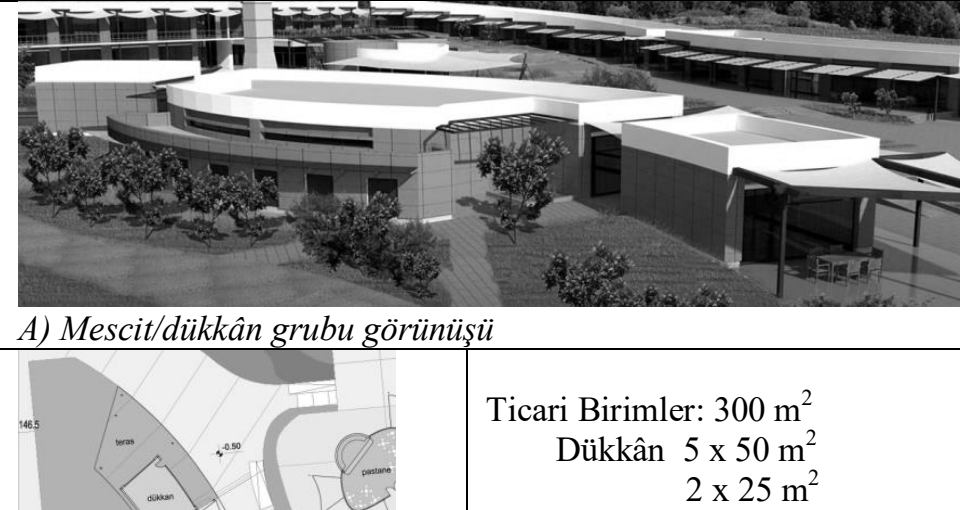

Mescit: $170 \mathrm{~m}^{2}\left(2 \times 85 \mathrm{~m}^{2}\right)$

(Bay ve bayan için wc ve abdest alma mahalli)

ATM Grubu: $75 \mathrm{~m}^{2}$ (7 adet ATM birimi ve jeneratör odası)

Yarı açık alan: $390 \mathrm{~m}^{2}$

Toplam Kapalı Alan: $545 \mathrm{~m}^{2}$

Toplam Yarı Açık Alan: $390 \mathrm{~m}^{2}$

\section{B) Mescit/dükkan grubu planı}

Çizelge 3. Pastane Yapısı mahal listesi ve alan kullanımı

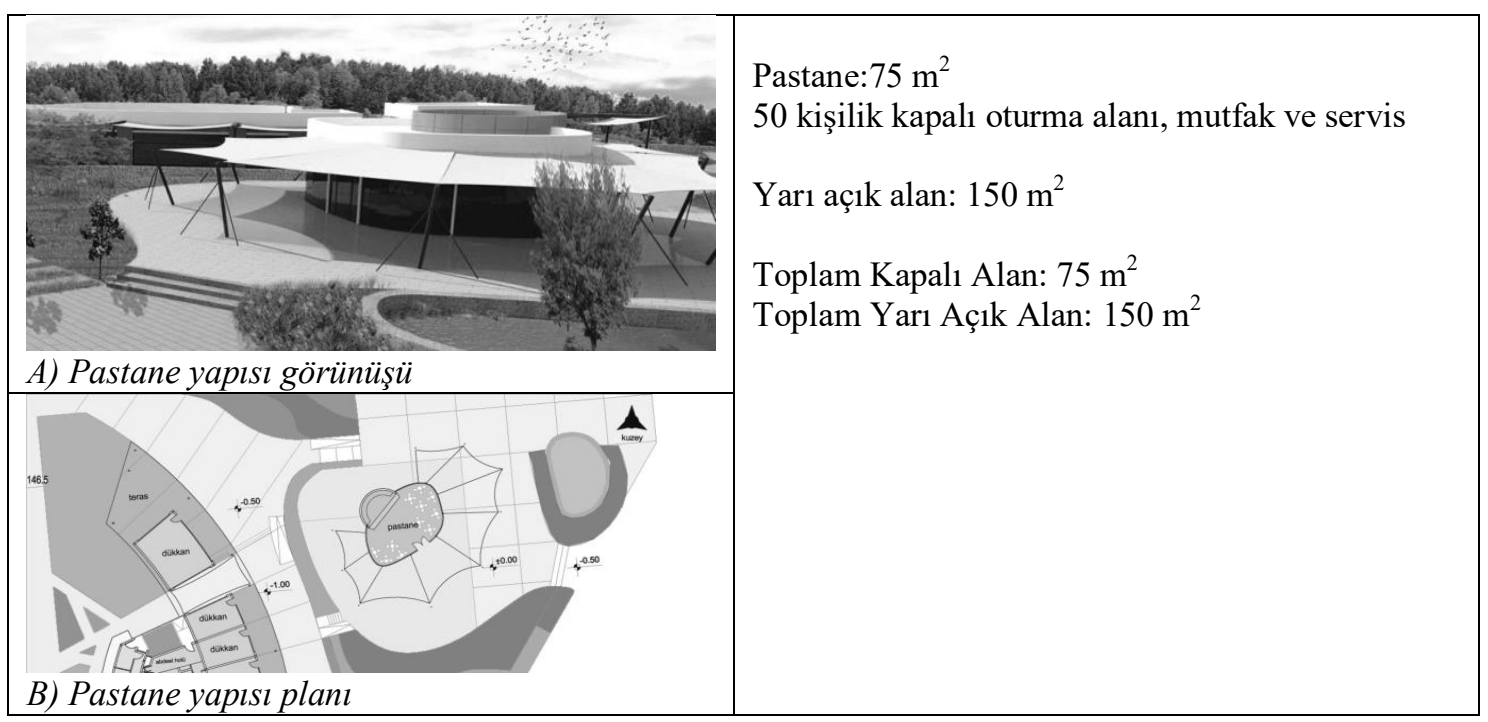


Çizelge 4. Kafe/Dükkan grubu yapısı mahal listesi ve alan kullanımı

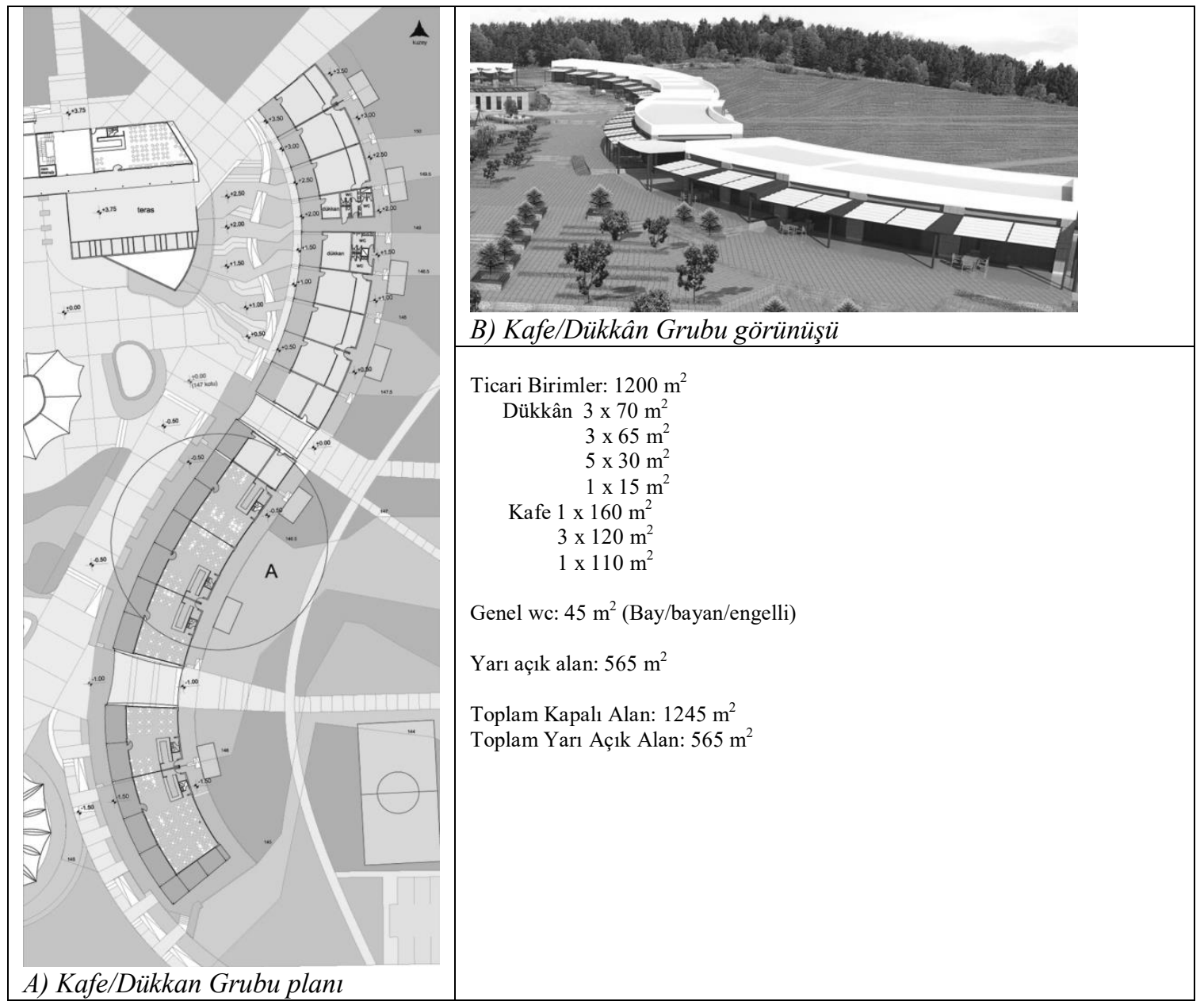

Alanı doğu yönünde sinırlayan Kafe Dükkan Grubu binası kullanıcılara farklı bakış açıları verecek şekilde biçimlendirilmiştir. Yapı arazinin topografyasına uyarak, kademeli olarak yükselir. Farklı kotlarda yer alan ticari birimler kullanıcılara alanı farklı kotlardan izleme imkanı sunar. Yapıda çeşitli büyüklükte modüler olarak tasarlanan dükkanların yanında genel kullanıma ait wc'ler bulunmaktadır (Çizelge 4).

\subsection{Dış Mekan Kullanımı}

Alanda yap1 yoğunluğu mümkün olduğunca düşük tutulmuş, yapılar alanının çeperlerine çekilerek dış mekanda yapı formuyla tanımlanan açık kullanım alanları oluşturulmaya çalıșılmıştır. Bölgenin iklim karakteri dikkate alınarak dıș mekan kullanımını destekleyen bir tasarım önerisi geliştirmeye gayret edilmiştir (Şekil 4). Dış mekanda farklı kullanımlara imkân tanımak ve aktivite alanlarını çeşitlendirmek amacıyla farklı kotlarda iki adet meydan düzenlenmeye çalışılmıştır. $\mathrm{R}$ grubu dersliklerden yaklaşan kullanıcılar için 147 kotunda üst meydan, yemekhane yönünden yaklaşan kullanıcılar için de 146 kotunda bir alt meydan düzenlenmiştir. $\mathrm{Bu}$ iki meydan alanda Mithat Özsan Amfisine doğru uzanan ve Kafe/Dükkân Grubu yapısının önünden geçen ana 
yaya yolu ile birbirine bağlanmıştır. $\mathrm{Bu}$ iki meydanı işaret etmek ve tanımlamak ayrıca alanın simgesel ve estetik değerini arttırmak amaciyla üst meydan için saat kulesi, alt meydan için de heykel yerleştirmesinin yapılacağı bir alan tasarlanmıştır. Farklı kotlara sahip dış mekanların tümünde eşitlikçi kullanım ve engelsiz tasarım ilkeleri gözetilmiş, alanın tümünde engelli ulaşımı dikkate alınmıștır. Dış mekanlar aktif ve pasif kullanıma yönelik düzenlenmiş, genel kullanıma ait açık alan düzenlemelerinin yanında alanın güney ucunda ayrıca iki adet basketbol sahası önerilmiştir.

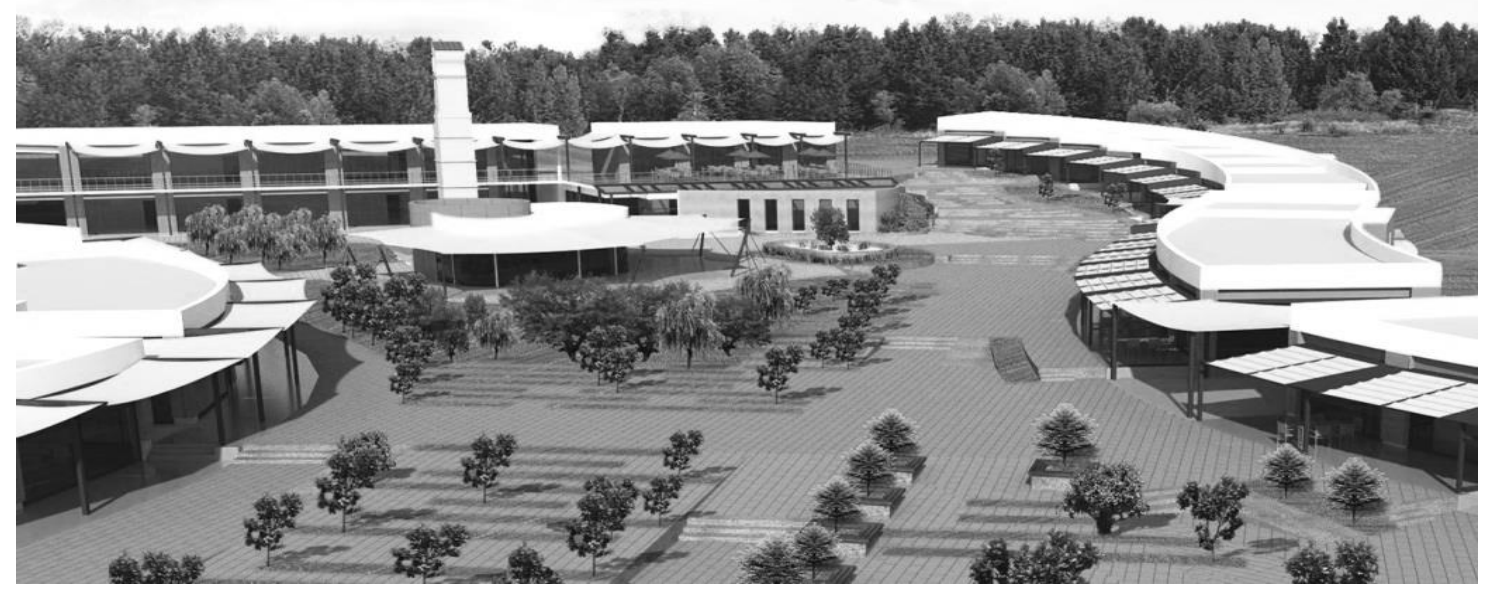

A) Alana güney yönünden bakış

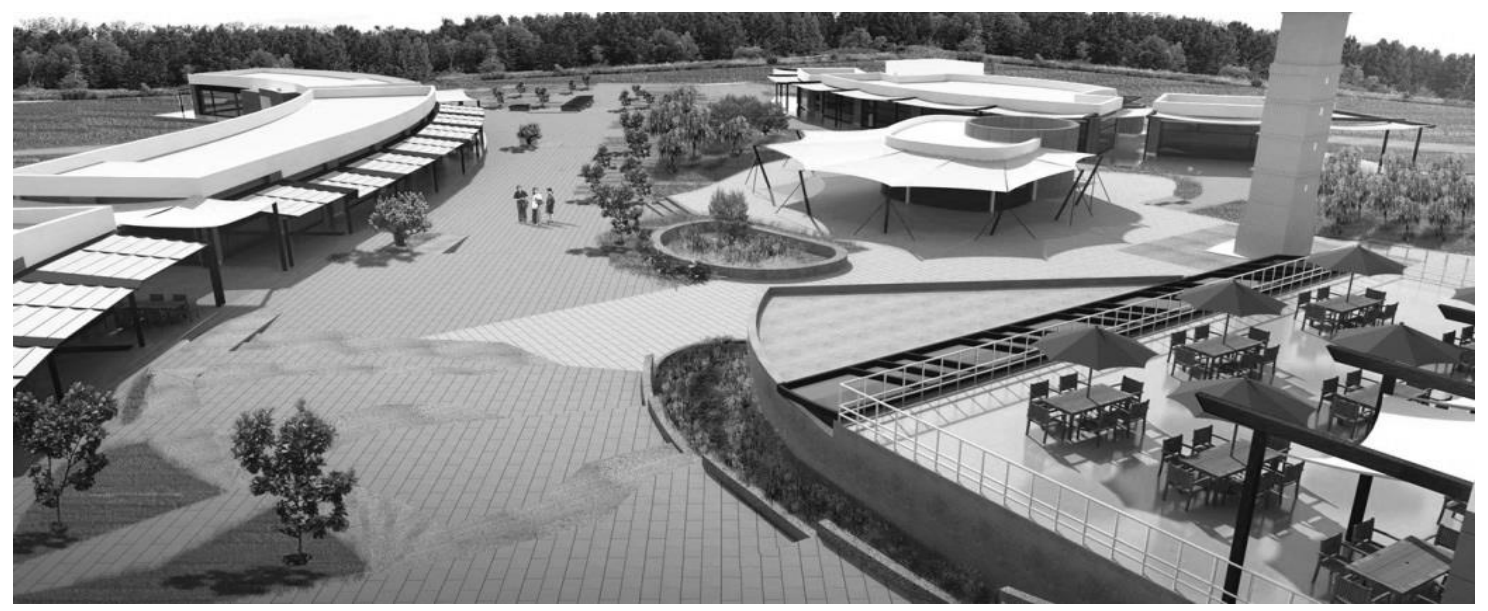

B) Alana kuzey yönünden bakış

Şekil 4. Önerilen yerleşimin genel görüntüleri

Alanda dükkân ve kafe gruplarının kullanımı için çeperlerden geçen ve mevcut otoparklara ulaşan servis bandı planlanmıştır. Ayrıca alana doğu yönünden bağlanarak 147 ve 145 kotlarına ulaşan geniş yaya bantları acil durumlar için araç geçişine imkan tanıyacak şekilde tasarlanmıştır (Şekil 5). 


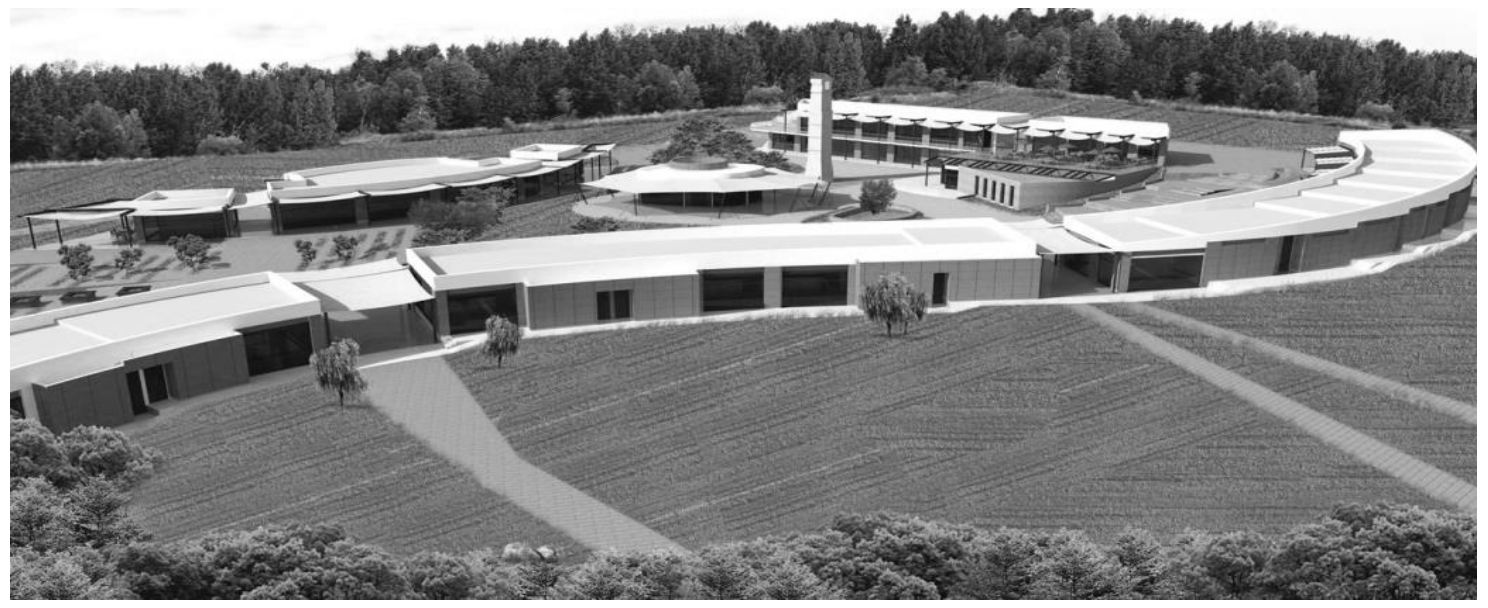

Şekil 5. Doğu yönünde yer alan servis bandı ve yaya yaklaşımları

\subsection{Tasarıma İlişkin Diğer Konular}

Çarşı kompleksinde ağırlıklı kullanımı kafe ve dükkân grupları oluşturmaktadır. $\mathrm{Bu}$ birimler modüler olarak tasarlanarak gerektiğinde ihtiyaca göre farklı mekân büyüklüklerinin sağlanması hedeflenmiştir. Esnek mekân büyüklüğüne ulaşabilme isteği taşıyıcı sistemin belirlenmesinde etkili olmuştur. Yapıların tümü için kompozit döşemeli çelik taşıyıcı sistem ile birlikte kullanım alanlarını sınırlamak ve tanımlamak için hafif bölücü elemanlar önerilmiştir. Bunlara ek olarak kafeler özellikle öğrencilerin eğitim dış1 zamanlarda yeme içme ihtiyaçlarının karşılanması yanında sosyalleşebilecekleri alanlar olarak düşünülmüş, kafe birimleri tasarlanırken farklı birimlerdeki kullanıcıların birbirlerini görmesi ve etkileşim halinde olması hedeflenmiştir. $\mathrm{Bu}$ amaçla iki kafe birimini ayırırken dolu yüzeyler yerine görsel iletişime olanak tanıyan ve dijital baskı uygulanabilen lamine cam bölücü yüzeyler önerilmiștir. Her bir kafe biriminin ortak yarı açık alana açılmasıyla istenilen etkileşimi desteklemesi hedeflenmiştir (Şekil 6, Şekil 7).

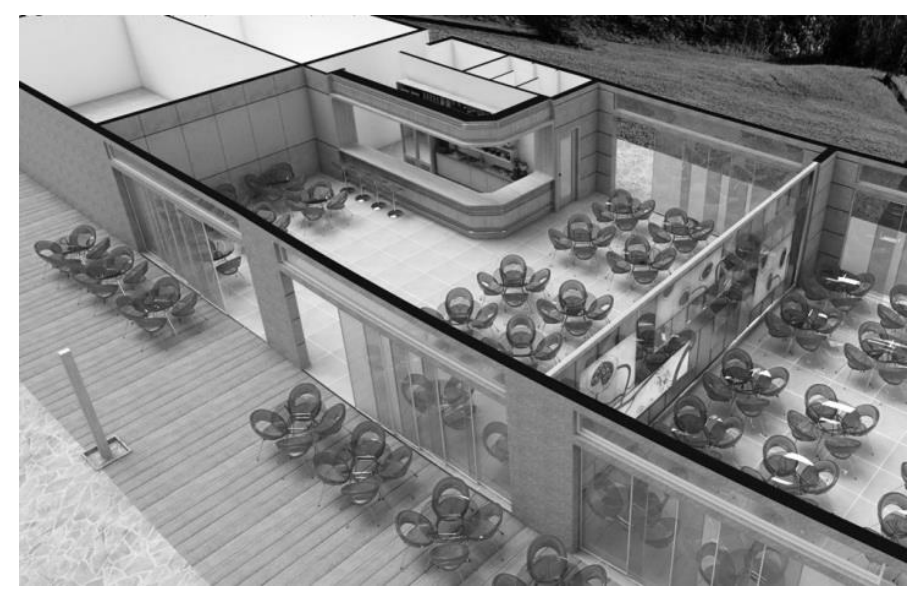

Şekil 6. Kafe birimlerinin organizasyonu ve dış mekanla ilişkisi 


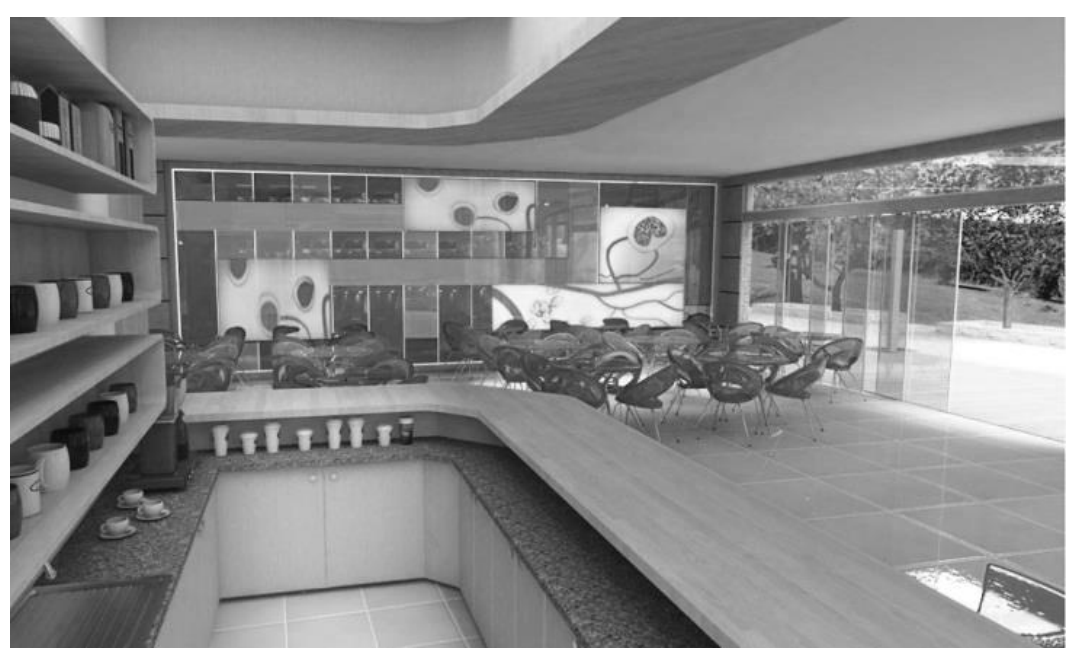

Şekil 7. Kafe biriminden iç mekan görüntüsü

\section{SONUÇ}

Üniversite kampüslerinde öğrenci merkezleri, öğrencilerin kampüs içindeki aktivitelerini zenginleştiren, öğrenciler arasındaki sosyal iletişimi ve etkileşimi arttıran mekânlardır. Bunun yanı sıra kampüs içindeki sosyal mekânlar öğrencilerin eğitim kurumu ile bağlılık ilişkisini ve eğitim kurumuna ait olma hissini olumlu yönde desteklemesi bakımından önemli bulunmaktadır. Önerilen projenin tamamlanmasıyla kampüsün fiziki mekânsal kullanım değerinin yükseltilmesinin yanında kampüsün sosyal ve kültürel yaşantısına katk1 sağlayacağ düşünülmektedir.

\section{TEŞEKKÜR}

Projenin bilgisayar ortamına aktarılması ve üç boyutlu görsellerinin hazırlanması sırasında emeği geçen ÇÜ MMF Mimarlık Bölümü öğrencileri Alparslan TUTAR, Burak DAĞ, Ali Furkan YÖNDER, Abdullah ALTUĞ ve Rukiye TÜTER'e teşekkür ederim. 